\title{
Mobile Apps in Retail: Determinants of Consumer Acceptance - A Systematic Review
}

\author{
https://doi.org/10.3991/ijim.v14i20.18273 \\ Atilla Wohllebe ( $\left.{ }^{\varpi}\right)$, Phyllis Dirrler \\ Szent István University, Kaposvár, Hungary \\ atilla.wohllebeegmail.com \\ Szilárd Podruzsik \\ Corvinus University of Budapest, Budapest, Hungary
}

\begin{abstract}
With the increasing relevance of smartphones, more and more companies are trying to use mobile apps for their business purposes. At the same time, the digital transformation and online trade are putting increasing pressure on the stationary retail trade. Many retailers are therefore looking for ways to use mobile apps to attract new customers or retain existing ones. With the growing number of mobile apps in the app marketplaces, the sustainable loyalty of app users is becoming an increasing challenge. For retailers, the question arises as to which determinants influence consumer acceptance of mobile apps in retail. From an initial 44,800 search results at Google Scholar, 18 scientific papers are analyzed in a qualitative synthesis by means of a systematic review based on the PRISMA schema. In general, perceived value, practical benefits and user-friendliness are identified as determinants. In addition, the importance of linking the mobile app to the stationary POS and the function of mobile apps in retail more as digital shopping assistants and less as online stores is highlighted. The retailer who publishes the app itself also plays an important role in the consumer acceptance of the app.
\end{abstract}

Keywords-Mobile Apps, Retail, Consumer Acceptance, Consumer Adoption, Systematic Review

\section{Introduction}

The spread of mobile devices or smartphones and the importance of these devices for accessing the Internet has been growing steadily for many years since the first smartphone was sold [1], [2]. At the same time, the importance of mobile applications, or mobile apps for short, is also growing: Apps now exist for practically all areas of life and are used by consumers [3], for example for vacations, education or in the health sector [4]-[8].

As a result, more and more companies are looking for ways to use mobile apps commercially [9]. Because mobile apps can also help to retain existing customers [10]-[12], commercial hopes are correspondingly high [13]. 
Parallel to these developments, stationary retail is under increasing pressure. Available retail space is still rising [14], while rents remain constant [15]. Following the in some cases significant declines in sales in the past [16], sales productivity in terms of sales per square meter of sales space is recovering slowly [17]. At the same time, the relevance of online retailing as a share of total retail sales is steadily growing steadily [18].

For the design of their local shopping experience, customers therefore increasingly expect technological innovation, such as self-scanning options, digital advertising for local offers or virtual opportunities to try on clothing based on augmented reality technologies [19]. Mobile apps could play a decisive role here, for example in payment processing or by checking the availability of goods online [3], [20]. At the same time, however, research from other contexts also shows that the development of mobile apps does not always match the expectations of potential users [21].

Scientific research has already frequently examined and demonstrated the use of mobile apps in the retail industry. For example, customers of a retailer who have installed the app generate more sales on average [22]. The actual use of the app plays an important role here, because customers who enjoy using a retailer's app are more likely to recommend it to others [23].

Previous research in the app context in general has already comprehensively investigated the factors that determine consumer acceptance of mobile apps. For example, in addition to consumer loyalty to a brand [24], [25], a functional, attractive design also plays an important role [26]. Further research results indicate that the perception mobile apps also seems to be determined by socio-economic background of people [27]. Furthermore, with regard to mobile apps, it is generally emphasized that actual added value, such as time savings, drives consumer acceptance [28].

This raises the question of what is causing consumers to adopt and actually use mobile apps in retail in particular. Using a systematic review this paper therefore investigates the determinants of consumer acceptance of mobile apps in retail.

\section{Methodology}

For the systematic review, the authors use the scientific database Google Scholar on August 12, 2020. The systematic review is methodically structured according to the PRISMA scheme [29].

Table 1 shows the procedure for searching and selecting literature as a review protocol. 
Table 1. Review Protocol

\begin{tabular}{|l|l|}
\hline Review Question & \multicolumn{1}{|c|}{ "What drives consumer acceptance of mobile app in retail?" } \\
\hline \multirow{2}{*}{ Literature Search } & Source: Google Scholar \\
\cline { 2 - 3 } & Search term: "mobile apps retail” \\
\hline Sorting & By relevance \\
\hline Filtering & Exclusion of patents and citations Years: 2016-2020 \\
\hline \multirow{2}{*}{ Exclusions } & By position in list: Only first 10 pages / 100 results \\
\cline { 2 - 2 } & $\begin{array}{l}\text { By title: Thematic reference given in the title in the broadest sense, excluding e.g. } \\
\text { entries focusing on mobile banking or gastronomy as well as mainly technological } \\
\text { concepts }\end{array}$ \\
\cline { 2 - 2 } & $\begin{array}{l}\text { By abstract: Exclusion of entries with no reference to mobile apps in retail or with no } \\
\text { recognizable reference to consumers and customers }\end{array}$ \\
\hline Evaluation & $\begin{array}{l}\text { Full-text assessment: Inclusion of only those articles with specific references to the } \\
\text { consumer acceptance of mobile apps in retail }\end{array}$ \\
\hline
\end{tabular}

The total of 44,800 search results for "mobile apps retail" will be reduced to 38,500 after exclusion of patents and citations. The subsequent restriction to results since 2016 or later reduces the results to a total of 23,200 . The restriction to the last five calendar years is made because the research field of mobile apps is still relatively new and technological developments are fast.

Sorted by relevance (at Google Scholar's discretion), the first 100 search results are then screened. The search results, which have probably been updated again and again in the meantime, can be called up at the in Ref. [30] web address.

Figure 1 shows the subsequent procedure according to the PRISMA statement [29].

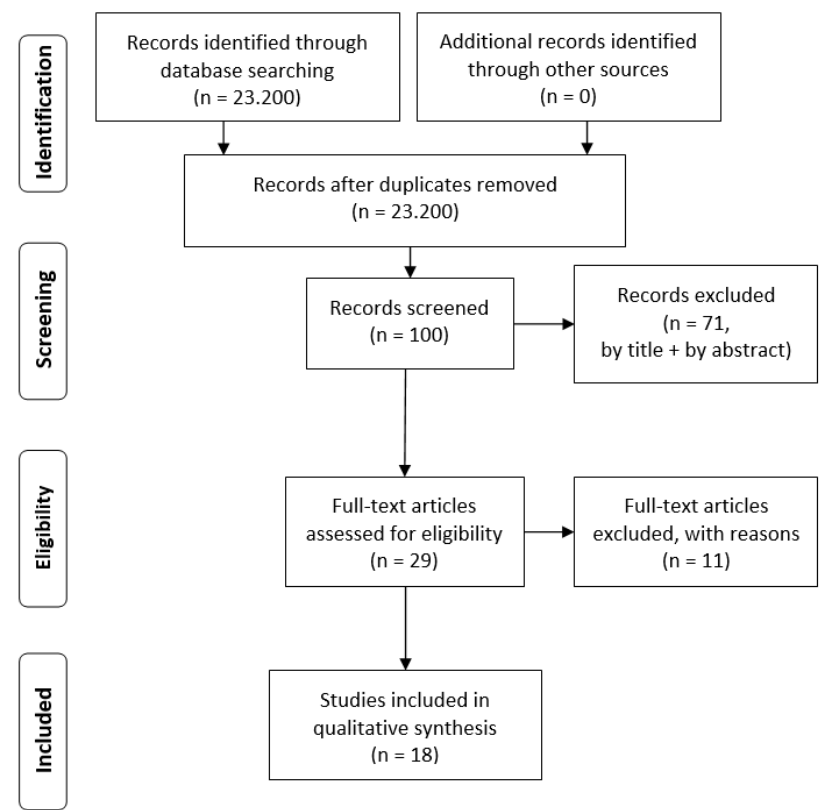

Fig. 1. PRISMA Statement (source: [29]) 
In the first screening, only those items that have a clear link to the retail trade are included in the next step, the full-text assessment for eligibility. This does not include articles on mobile banking [31] and purely technological concepts in the broadest sense [32]. Also articles from other business areas such as gastronomy have not been included [33].

In the subsequent full-text assessment, a further 11 of 29 articles are excluded. Examples of excluded articles are:

- An article that examines how a retailer in China can use the WeChat app as a mobile instant messaging application to build customer relationships. As this is not the retailer's own app, but the WeChat app is used as a third-party provider, the article is excluded [34].

- An article that examines web and app as access routes to the retail market in India. Because it is only a two-page case study, this article is also excluded [35].

- An article on mobile payment technologies in retail is also excluded: The article focuses on mobile payment and not on retail [36].

After the full-text assessment and dropping eleven articles, 18 journal articles, books, book chapters and articles from conference proceedings are included in the qualitative synthesis.

\section{$3 \quad$ Results}

In the following, the articles are summarized in the context of the qualitative synthesis and references to the question of consumer acceptance factors are established. The review increases in chronological order from year to year. Papers published in the same year increase in alphabetical order, according to the surname of the first author.

A study comparing technological innovations in retail via apps or via stationary installed devices comes to the conclusion, that previously piloted technical solutions have experienced rather moderate acceptance. Based on an online survey of consumers, the authors emphasize the importance of emotions. Also, the importance of joy trying out new solutions is pointed out. At the same time, they also leave open what could drive consumer acceptance of mobile apps in retail in the long term beyond the mere joy of innovation [37].

In a qualitative research with 29 consumers, Ref. [38] investigates the willingness of consumers to change their shopping behavior using mobile technologies. The authors consider this question for Italy and in particular against the background of click and collect procedures or so-called pick-up boutiques. They come to the conclusion that consumers would like to see more use of mobile apps as shopping aids. The stronger connection of mobile technologies with the physical store on site plays a strong role for consumer acceptance and thus for the long-term success of mobile apps in retail.

Ref. [39] investigate the motivation for app engagement in the context of a fashion retail app by means of 18 qualitative interviews within the framework of explorative research. They distinguish between hedonic and utilitarian motivations. As a result, 
they conclude that efficiency and convenience are the most important utilitarian motivators. They also stress the importance of personalized service and convenient operation processes. Their statement is important for the long-term consumer acceptance of mobile apps in retail: The authors clearly distinguish themselves from the industry's usual focus on experiential interactions in this context.

Using a quantitative analysis of 272 shopping apps and a survey, Ref. [40] investigates how the use of mobile augmented reality apps in retail can create added value for customers. The author finds that augmented reality technologies basically have the potential to improve the retail shopping experience and thus contribute to consumer acceptance.

By surveying 630 U.S. consumers and processing a SEM and an ANOVA, Ref. [41] investigates augmented reality apps in fashion retail in the USA. In particular, the impact of trust in AR applications on the use of these applications and visiting a retail store is investigated. As a result, it is concluded that novelty is positively related to trust and trust is positively related to the intention to visit a retail store. With this research, the author shows an important connection how mobile apps can help retailers to increase store visits. Therefore, they emphasize engaging with existing app users. Consequently, trust in an app not only contributes to app usage but also to the increase of store visits.

A survey of 146 consumers using smartphones in retail stores was conducted to find differences by product category and gender. In particular, the authors find that high involvement product categories and young men are particularly affine to using smartphones and mobile apps in retail stores. This means that consumer acceptance of mobile apps in retail stores also depends on the context in which they are used [42].

Ref. [43] investigate the impact of mobile apps in retail and their impact on customer satisfaction in the multichannel environment. On the basis of collected user data they find out that hedonic and functional aspects have a positive effect on customer satisfaction. They also point out that the congruence between retailer image and mobile app leads to higher customer satisfaction. With regard to the long-term acceptance of mobile apps in retail by consumers, the importance of the image of a retailer is to be emphasized. Besides, hedonic and functional aspects play an important role.

Investigating the antecedents and consequences of mobile app engagement, the authors of Ref. [44] find that time convenience, interactivity and compatibility have a positive influence on mobile app engagement and can lead to a strengthening of selfbranded connections. They confirm the importance of time convenience and practical benefits for long-term app usage by consumers.

A similar conclusion was reached by the authors of Ref. [45]: The authors examine the influence of consumer experiences with mobile retail apps on the intentions of use and recommendation. They also take into account channel preferences and purchasing behavior. They refer to retailers who sell via an app as well as via a store. They show that the perceived ease of use in particular has an effect on channel preferences and purchasing behavior as well as on future purchasing intentions. Their results underline the importance of a user-friendly implementation on consumer acceptance. 
Trust, privacy, learning and relaxation features also play an important role. This can be derived from the work of Ref. [46]: The authors compare models for the use and continuous use of mobile apps in retail and use the unified theory of acceptance and use of technology.

Examining mobile technologies as drivers of digital change in retail, a review of existing scientific literature and other popular sources conclude that digital channels such as mobile apps should not be understood as a mere distribution channel. Rather, the authors emphasize the importance of embedding them in a holistically thought-out multichannel strategy. In this respect, consumer expectations of mobile apps in retail should not only be considered from the perspective of a distribution channel. This might not be sufficient for long-term consumer acceptance [47].

Using eye tracking and scan path visualizations, the authors of Ref. [48] capture consumer shopping behavior on smartphones in fashion retail. They identify various usability issues. Their work also emphasizes the importance of a user-friendly application and a development that is strongly oriented towards the needs and habits of the users. This can ensure the user acceptance.

Understanding the intention to reuse as an expression of long-term consumer acceptance, Ref. [49] demonstrates the importance of mobile app atmospherics. The authors develop and test a model to define the relationships between hedonic shopping orientation, consumer need for mobile apps atmospherics, entertainment gratification, mobile irritation and the intention to reuse mobile apps. In the context of apparel shopping, they develop a model, which they test with 216 US mobile shoppers between 18 and 34: The mobile app atmospherics plays a central role in the intention to reuse mobile apps.

In the context of the disruption of traditional retail through mobile technologies, Ref. [50] presents various building blocks for the use of mobile in retail. They state that the exclusive adaptation of known e-commerce systems and functionalities is not sufficient to meet the needs of mobile digitization of stationary retail from the customer's perspective. Their results are decisive for the question of consumer acceptance of mobile apps in retail, since a mobile app of a retailer must offer more than just a shopping functionality.

A similar conclusion can be reached on the basis of a study that uses a crosssection survey to examine the impact of e-service quality on customer loyalty, using Zara and Mango as examples. The authors emphasize the importance of mobile app design, but also show that return handling policies and price offerings are important for customer loyalty. Their work is interesting for consumer acceptance in so far as, in addition to the app itself, the services of a retailer are also important to strengthen the long-term use of mobile apps by retailers [51].

With a view to food retailing, the authors of Ref. [52] examine how mobile apps affect customer loyalty in this area. The authors work out that the perceived value of an app by users positively contributes to cognitive and conative loyalty. With a view to long-term user acceptance, this finding is central in that it emphasizes the importance of actual added value for the customer.

In a grocery store with the example of fresh salmon, the use of mobile apps as a tool to support the purchase decision is examined. The study uses a conjoint experi- 
ment with 90 participants. The authors find out that quality indicators of other customers as well as individual offers in particular contribute to the usefulness of an app and thus contribute to a higher consumer acceptance [53].

The last paper considered here shows the antecedents and consequences of consumer confidence in mobile retails apps in India. Using a SEM and data from a survey of 567 participants, the authors show that previous consumer experience, the usefulness of an app, the ease of use and quality of the app, and the reputation and offline presence of an organization have a positive impact on consumer trust in mobile apps. They emphasize the central role of trust in the adoption of apps in retail. At the same time, they emphasize that the app alone is not enough, but that the retailer also contributes significantly to consumer acceptance of mobile apps in retail [54].

\section{$4 \quad$ Summary and Discussion}

For this systematic review on the question, which determinants affect the consumer acceptance of mobile apps in retail, a total of 18 were filtered out and analyzed for the qualitative synthesis on the basis of initial 44,800 papers.

First of all, it should be emphasized that the acceptance of a mobile app in retail always depends on the specific context in which it is used - product categories with a high level of involvement are particularly suitable for the use of mobile apps [42].

In summary, the acceptance of mobile apps in retail is primarily determined by expected efficiency gains, practical benefits and user-friendliness [39], [44], [48]. The perceived value of an app plays a major role, especially for long-term consumer acceptance [52]. The role of trust and respect for privacy are also described as determinants [41], [46], [54] and can even contribute to increasing store visits [41]. These results do not particularly differ from previous findings on consumer acceptance of mobile apps in general.

From a functional point of view, mobile apps in retail should not only represent a distribution channel (in the sense of m-commerce), but should rather be understood and developed as digital shopping assistants for in-store shopping. A mobile app as a pure online shopping tool without any reference to the stationary point of sale is not sufficient for long-term consumer acceptance [38], [47], [50].

It is also noteworthy that the retailer itself, as a brand and with the services it offers, apparently also has a major influence on consumer acceptance of the mobile app it offers, as is repeatedly emphasized [43], [51], [54].

Regarding the limitation it is to be noted that Google Scholar is a comprehensive, but also quite broad database. In particular when sorting the search results by relevance, Google Scholar's definition was used. The search engine's understanding of relevance is not necessarily consistent with other bibliographic methods and is not completely transparent.

Regarding the remaining research gaps, two aspects in particular are identified. First, there seem to be different user typologies in the use of mobile apps in retail, as a certain joy of trying new innovations identified by Ref. [37] or the use of an app as an online store or digital shopping assistant outlined by Ref. [47], [50] suggest. Second- 
ly, the question arises as to what specific functionality retailers are trying to use to meet this consumer demand.

\section{Conclusion}

The aim of this paper was to present current scientific findings on the determinants of consumer acceptance of mobile apps in retail by means of a systematic review. Using the scientific database Google Scholar a total of 18 current journal articles, articles from conference proceedings and book chapters were identified in a qualitative synthesis.

It can be stated that many determinants in the case of mobile apps in retail are similar to those of mobile apps in general: User friendliness, added value for the user and user trust in the app play essential role. In addition, the retailer offering the mobile app is particularly important for mobile apps in retail. The strength of their brand, a positive image and the service offered also have a positive impact on the acceptance of the mobile app.

The functionality of the mobile app should be emphasized in particular: Consumers expect less of a sales channel in the sense of a mobile online store, but rather a digital shopping assistant that helps them with their local retail purchases.

At the same time, the results shown also raise the question of different user typologies of mobile apps in retail and the question of the concrete answer to the expectation of a digital shopping assistant in terms of concrete features.

\section{References}

[1] IDC, “Smartphones - Quartalsabsatz bis Q2 2020,” Statista, 2020. https://de.statista.com/ statistik/daten/studie/246300/umfrage/weltweiter-absatz-von-smartphones-nach-quartalen/ (accessed Aug. 26, 2020).

[2] StatCounter, "Anteil mobiler Endgeräte an allen Seitenaufrufen nach Regionen weltweit im Jahr 2018," Statista, 2019. https://de.statista.com/statistik/daten/studie/217457/umfrage/ anteil-mobiler-endgeraete-an-allen-seitenaufrufen-weltweit (accessed Dec. 31, 2019).

[3] PwC, "Apps - Nutzung in Europa nach Altersgruppen 2018," Statista, 2020. https://de.statista.com/statistik/daten/studie/1127213/umfrage/nutzung-von-apps/ (accessed Aug. 26, 2020).

[4] BITKOM, "Mobile Apps - Nutzung auf Reisen in Deutschland 2020," Statista, 2020. https:/de.statista.com/statistik/daten/studie/728171/umfrage/nutzung-von-apps-auf-reisenin-deutschland/ (accessed Aug. 26, 2020).

[5] M. A. Saare, A. Hussain, and W. S. Yue, "Conceptualizing Mobile Health Application Use Intention and Adoption Among Iraqian Older Adults: From the Perspective of Expanded Technology Acceptance Model," International Journal of Interactive Mobile Technologies (iJIM), vol. 13, no. 10, Art. no. 10, Sep. 2019, https://doi.org/10.3991/ijim.v13i10.11285.

[6] H.-J. Kim and J.-Y. Rha, "Predicting the Drivers of the Intention to Use Mobile Learning in South Korea," International Journal of Interactive Mobile Technologies (iJIM), vol. 12, no. 1, Art. no. 1, Jan. 2018, https://doi.org/10.3991/ijim.v12i1.7688. 
[7] S. Papadakis and M. Kalogiannakis, Eds., "A Research Synthesis of the Educational Value of Self-proclaimed Mobile Educational Applications for Young Age Children," in Mobile Learning Applications in Early Childhood Education, Hershey, PA: IGI Global, 2020.

[8] M. Kalogiannakis and S. Papadakis, "Evaluating pre-service kindergarten teachers' intention to adopt and use tablets into teaching practice for natural sciences," IJMLO, vol. 13, no. 1, p. 113, 2019, https://doi.org/10.1504/IJMLO.2019.096479.

[9] AppBrain, "Google Play Store - Anzahl der Apps 2020," Statista, 2020. https://de.statista.com/statistik/daten/studie/74368/umfrage/anzahl-der-verfuegbaren-appsim-google-play-store/ (accessed Aug. 26, 2020).

[10] A. Wohllebe, "Consumer Acceptance of App Push Notifications: Systematic Review on the Influence of Frequency," International Journal of Interactive Mobile Technologies (iJIM), vol. 14, no. 13, 2020, https://doi.org/10.3991/ijim.v14i13.14563.

[11] D. S. Verma and D. Verma, "Managing Customer Relationships through Mobile CRM In Organized retail outlets," International Journal of Engineering Trends and Technology IJETT, vol. 4, no. 5, pp. 1697-1701, 2013, Accessed: Jul. 12, 2020. [Online]. Available: http://ijettjournal.org/archive/ijett-v4i5p76.

[12] N. Allurwar, B. Nawale, and S. Patel, "Beacon for Proximity Target Marketing," International Journal Of Engineering And Computer Science, vol. 5, no. 5, pp. 16359-16364, 2016, https://doi.org/10.18535/IJECS/V5I5.08.

[13] BITKOM, "Aus Entwicklersicht: Was sind die vorrangigen Gründe für Ihr Unternehmen in die Entwicklung mobiler Anwendungen zu investieren?," Statista, 2011. https://de.statista.com/statistik/daten/studie/196892/umfrage/beweggruende-vonunternehmen-fuer-die-entwicklung-von-apps/ (accessed Oct. 19, 2019).

[14] HDE, "Verkaufsfläche im Einzelhandel in Deutschland bis 2018," Statista, 2019. https://de.statista.com/statistik/daten/studie/462136/umfrage/verkaufsflaeche-imeinzelhandel-in-deutschland/ (accessed Dec. 27, 2019).

[15] BulwienGesa, DZ Bank, and Scope, "Einzelhandelsimmobilien - Spitzenmiete nach Städten in Deutschland bis 2020," Statista, 2019. https://de.statista.com/statistik/daten/studie/ 181016/umfrage/spitzenmieten-von-einzelhandelsimmobilien-in-deutschland-nachstaedten/ (accessed Dec. 27, 2019).

[16] Statistisches Bundesamt, "Umsatzentwicklung im Einzelhandel in Deutschland bis 2019," Statista, 2020. https://de.statista.com/statistik/daten/studie/70190/umfrage/umsatz-imdeutschen-einzelhandel-zeitreihe/ (accessed Dec. 27, 2019).

[17] HDE, Statista, KPMG, and bevh, "Flächenproduktivität im Einzelhandel in Deutschland bis 2018," Statista, 2019. https://de.statista.com/statistik/daten/studie/214701/umfrage/ flaechenproduktivitaet-im-deutschen-einzelhandel/ (accessed Dec. 27, 2019).

[18] Statistisches Bundesamt, "Umsatzanteil des eCommerce im Einzelhandel in Deutschland," Statista, 2020. https://de.statista.com/statistik/daten/studie/261395/umfrage/umsatzanteildes-ecommerce-im-einzelhandel-in-deutschland/ (accessed Aug. 26, 2020).

[19] HDE, "Kundenerwartung zu technischen Erneuerungen im Einzelhandel in Deutschland 2018," Statista, 2018. https://de.statista.com/statistik/daten/studie/829480/umfrage/kunden erwartung-zu-technischen-erneuerungen-im-einzelhandel-in-deutschland/ (accessed Aug. 26, 2020)

[20] IfH Köln, "Erwartungen an Cross Channel Angebote im Einzelhandel von Innenstädten nach Einwohnerzahl in Deutschland 2018 I Umfrage," Statista, 2019. https://de.statista.com/statistik/daten/studie/988859/umfrage/umfrage-zu-cross-channelangeboten-im-einzelhandel-von-innenstaedten-nach-einwohnerzahl-in-deutschland//accessed Aug. 26, 2020). 
[21] S. Papadakis, M. Kalogiannakis, and N. Zaranis, "Educational apps from the Android Google Play for Greek preschoolers: A systematic review," Computers \& Education, vol. 116, pp. 139-160, Jan. 2018, https://doi.org/10.1016/j.compedu.2017.09.007.

[22] H. J. van Heerde, I. M. Dinner, and S. A. Neslin, "Engaging the unengaged customer: The value of a retailer mobile app," International Journal of Research in Marketing, vol. 36, no. 3, pp. 420-438, 2019, https://doi.org/10.1016/j.ijresmar.2019.03.003.

[23] L. Stocchi, N. Michaelidou, N. Pourazad, and M. Micevski, "The rules of engagement: how to motivate consumers to engage with branded mobile apps," Journal of Marketing Management, vol. 34, no. 13-14, pp. 1196-1226, Sep. 2018, https://doi.org/10.1080/0267 257X.2018.1544167.

[24] S. Bellman, S. Treleaven-Hassard, J. Robinson, D. Varan, and R. Potter, "Brand communication with branded smartphone apps: First insights on possibilities and limits," GfK Marketing Intelligence Review, vol. 5, no. 2, pp. 24-27, 2013.

[25] K.-F. Peng, Y. Chen, and K.-W. Wen, "Brand relationship, consumption values and branded app adoption," Industrial Management \& Data Systems, vol. 114, no. 8, pp. 1131-1143, Jan. 2014, https://doi.org/10.1108/IMDS-05-2014-0132.

[26] K. Kang, J. Lu, L. Guo, and J. Zhao, "How to Improve Customer Engagement: A Comparison of Playing Games on Personal Computers and on Mobile Phones," J. theor. appl. electron. commer. res., vol. 15, no. 2, pp. 0-0, 2020, https://doi.org/10.4067/S071818762020000200106.

[27] S. Papadakis, N. Zaranis, and M. Kalogiannakis, "Parental involvement and attitudes towards young Greek children's mobile usage," International Journal of Child-Computer Interaction, vol. 22, p. 100144, Dec. 2019, https://doi.org/10.1016/j.ijcci.2019.100144.

[28] M. Rojas-Osorio and A. Alvarez-Risco, "Intention to Use Smartphones among Peruvian University Students," International Journal of Interactive Mobile Technologies (iJIM), vol. 13, no. 03, Art. no. 03, Mar. 2019, https://doi.org/10.3991/ijim.v13i03.9356.

[29] D. Moher, A. Liberati, J. Tetzlaff, D. G. Altman, and T. P. Group, "Preferred Reporting Items for Systematic Reviews and Meta-Analyses: The PRISMA Statement," PLOS Medicine, vol. 6, no. 7, p. e1000097, Jul. 2009, https://doi.org/10.1371/journal.pmed.1000097.

[30] "mobile apps retail - Google Scholar," Google Scholar, 2020. https://scholar.google.com/scholar?as ylo=2016\&q=mobile+apps+retail\&hl=de\&as $\quad \mathrm{sdt}=1$ ,5\&as_vis=1 (accessed Aug. 12, 2020).

[31] P. Thusi and D. K. Maduku, "South African millennials' acceptance and use of retail mobile banking apps: An integrated perspective," Computers in Human Behavior, vol. 111, p. 106405, Oct. 2020, https://doi.org/10.1016/j.chb.2020.106405.

[32] N. Moorhouse, M. C. tom Dieck, and T. Jung, "Technological Innovations Transforming the Consumer Retail Experience: A Review of Literature," in Augmented Reality and Virtual Reality: Empowering Human, Place and Business, T. Jung and M. C. tom Dieck, Eds. Cham: Springer International Publishing, 2018, pp. 133-143.

[33] A. P. Kapoor and M. Vij, "Technology at the dinner table: Ordering food online through mobile apps," Journal of Retailing and Consumer Services, vol. 43, pp. 342-351, Jul. 2018, https://doi.org/10.1016/j.jretconser.2018.04.001.

[34] D. Vazquez, C. Dennis, and Y. Zhang, "Understanding the effect of smart retail brand Consumer communications via mobile instant messaging (MIM) - An empirical study in the Chinese context," Computers in Human Behavior, vol. 77, pp. 425-436, Dec. 2017, https://doi.org/10.1016/j.chb.2017.08.018.

[35] A. Vashisht, B. Wadhwa, and N. Phutela, "Who Leads the Game in Indian Retail: Web or Apps?-a Case of Flipkart," International Journal of Scientific Research, vol. 5, no. 2, pp. 
333-334, 2016, [Online]. Available: https://www.researchgate.net/publication/324724124 Who_Leads_the_Game_in_Indian_Retail_Web_or_Apps-a_Case_of_Flipkart.

[36] E. Taylor, "Mobile payment technologies in retail: a review of potential benefits and risks," International Journal of Retail \& Distribution Management, vol. 44, no. 2, pp. 159 177, Jan. 2016, https://doi.org/10.1108/IJRDM-05-2015-0065.

[37] S. Kheiravar and N. Richter, "Neue Technologien im stationären Einzelhandel: Mobile Apps oder stationäre Geräte?," in Digitalisierung im Vertrieb: Strategien zum Einsatz neuer Technologien in Vertriebsorganisationen, L. Binckebanck and R. Elste, Eds. Wiesbaden: Springer Fachmedien, 2016, pp. 609-631.

[38] E. Pantano and C.-V. Priporas, "The effect of mobile retailing on consumers' purchasing experiences: A dynamic perspective," Computers in Human Behavior, vol. 61, pp. 548555, Aug. 2016, https://doi.org/10.1016/j.chb.2016.03.071.

[39] C. J. Parker and H. Wang, "Examining hedonic and utilitarian motivations for mcommerce fashion retail app engagement," Journal of Fashion Marketing and Management: An International Journal, vol. 20, no. 4, pp. 487-506, Jan. 2016, https://doi.org/10.1108/JFMM-02-2016-0015.

[40] S. G. Dacko, "Enabling smart retail settings via mobile augmented reality shopping apps," Technological Forecasting and Social Change, vol. 124, pp. 243-256, Nov. 2017, https://doi.org/10.1016/j.techfore.2016.09.032.

[41] J.-Y. M. Kang, "Augmented Reality Mobile Apps in Fashion Retail: Expectancy-Value Judgments," International Textile and Apparel Association Annual Conference Proceedings, vol. 74, no. 1, Art. no. 1, 2017, Accessed: Aug. 30, 2020. [Online]. Available: https://www.iastatedigitalpress.com/itaa/article/id/1794/.

[42] N. Eriksson, C.-J. Rosenbröijer, and A. Fagerstrøm, "Smartphones as decision support in retail stores - The role of product category and gender," Procedia Computer Science, vol. 138, pp. 508-515, 2018, https://doi.org/10.1016/j.procs.2018.10.070.

[43] P. Iyer, A. Davari, and A. Mukherjee, "Investigating the effectiveness of retailers' mobile applications in determining customer satisfaction and repatronage intentions? A congruency perspective," Journal of Retailing and Consumer Services, vol. 44, pp. 235-243, Sep. 2018, https://doi.org/10.1016/j.jretconser.2018.07.017.

[44] S. Kim and T. H. Baek, "Examining the antecedents and consequences of mobile app engagement," Telematics and Informatics, vol. 35, no. 1, pp. 148-158, Apr. 2018, https://doi.org/10.1016/j.tele.2017.10.008.

[45] C. L. Newman, K. Wachter, and A. White, "Bricks or clicks? Understanding consumer usage of retail mobile apps," Journal of Services Marketing, vol. 32, no. 2, pp. 211-222, Jan. 2018, https://doi.org/10.1108/JSM-08-2016-0289.

[46] S. A. Olaleye, S. T. Sanusi, and B. Adepoju, "Actual Use and Continuous Use of Retail Mobile App: A Model Comparison Perspective,” ASTES, vol. 3, no. 6, pp. 151-158, 2018, [Online]. Available: http://jultika.oulu.fi/files/nbnfi-fe2018113049602.pdf.

[47] P. S. Shukla and P. V. Nigam, "E-Shopping using Mobile Apps and the Emerging Consumer in the Digital Age of Retail Hyper personalization: An Insight," PBR, vol. 10, no. 10, pp. 131-139, 2018, [Online]. Available: http://www.pbr.co.in/2018/2018 month/ April/16.pdf.

[48] Z. Tupikovskaja-Omovie and D. Tyler, "Mobile consumer shopping journey in fashion retail: eye tracking mobile apps and websites," in Proceedings of the 2018 ACM Symposium on Eye Tracking Research \& Applications, Warsaw Poland, Jun. 2018, pp. 1-3, https://doi.org/10.1145/3204493.3208335. 
[49] Y. Lee and H.-Y. Kim, "Consumer need for mobile app atmospherics and its relationships to shopper responses," Journal of Retailing and Consumer Services, vol. 51, pp. 437-442, Nov. 2019, https://doi.org/10.1016/j.jretconser.2017.10.016.

[50] R. Bodmeier, D. Scheck, and K. Lieber, "Mobile Eats the Retail World," in Handel mit Mehrwert, Accenture GmbH, G. Heinemann, H. M. Gehrckens, and T. Täuber, Eds. Wiesbaden: Springer Fachmedien Wiesbaden, 2019, pp. 135-152.

[51] J. T. F. Rosa, "How does mobile apps' e-service quality impact customer loyalty? : investigating the effect of customer satisfaction within the purchase experience," May 2019, Accessed: Aug. 30, 2020. [Online]. Available: https://repositorio.ucp.pt/handle/10400. $14 / 28998$.

[52] I. Beeck, H. Kriegesmann, and W. Toporowski, "Wirkung von mobilen Apps im Lebensmitteleinzelhandel auf die Kundenloyalität," in Perspektiven des Dienstleistungsmanagements : Aus Sicht von Forschung und Praxis, S. Roth, C. Horbel, and B. Popp, Eds. Wiesbaden: Springer Fachmedien, 2020, pp. 635-654.

[53] A. Fagerstrøm, N. Eriksson, and V. Sigurdsson, "The Use of Mobile Apps to Facilitate Customers' Choice-Making When Grocery Shopping," in Smart Trends in Computing and Communications: Proceedings of SmartCom 2020, Singapore, 2020, pp. 39-47, https://doi.org/10.1007/978-981-15-5224-3_4.

[54] A. K. Kaushik, G. Mohan, and V. Kumar, "Examining the Antecedents and Consequences of Customers' Trust Toward Mobile Retail Apps in India," Journal of Internet Commerce, vol. 19, no. 1, pp. 1-31, Jan. 2020, https://doi.org/10.1080/15332861.2019.1686333.

\section{$7 \quad$ Authors}

Atilla Wohllebe is a PhD student at the Doctoral School in Management and Organizational Sciences, Szent István University - Kaposvár Campus, Hungary. Living and working in Hamburg, Germany, he is engaged in research and professional work on consumer interactions with smartphone apps. Atilla Wohllebe holds a B.A. in Business Administration and a M.Sc. in E-Commerce.

Phyllis Dirrler lives in Hamburg, Germany, and conducts research in the fields of conflict management, aviation and digitalization. She is currently completing a $\mathrm{PhD}$ program at Szent István University - Kaposvár Campus, Hungary.

Szilárd Podruzsik is an associate professor at Corvinus University of Budapest. He works at the Institute for the Development of Enterprises. He also works as a supervisor at Kaposvár University and Szent István University. He holds a PhD from the Budapest University of Economics. His research focus is on small and medium-sized enterprises, food production, consumption and their determinants. He has already published over eighty papers as an author or co-author and participated in several research projects as a leader or participant.

Article submitted 2020-09-06. Resubmitted 2020-09-25. Final acceptance 2020-09-25. Final version published as submitted by the authors. 